\title{
The Asian Anthropocene: Electricity and Fossil Developmentalism
}

\author{
Elizabeth Chatterjee \\ Forthcoming in the Journal of Asian Studies \\ Pre-proof final version
}

\begin{abstract}
Much scholarship extrapolates global narratives of the Anthropocene from the "fossil capitalism" of European imperial powers. This analysis deploys the alternative lens of grid electricity - the great macro-technology of the twentieth century-to reevaluate the dynamics of the Anthropocene outside the Anglozone. Histories of Asian electrification refute the notion of any simple relationship between colonialism and fossil capitalism. Instead, they point towards a postcolonial trend of fossil developmentalism. Especially in the context of late development, energy expansion became a state-led moral project. Cutting against fossil capitalism's logic of commodification, electricity provision was increasingly conceptualized as a national good and an entitlement, even if one honored in the breach. This trend transcended the distinction between market and planned economies, and extended beyond formal democracies. The (partial) democratization of consumption brought by fossil developmentalism is the hallmark of the “Great Acceleration” in human impacts on the environment since 1950.
\end{abstract}




\section{Introduction}

The comparative stability of the Holocene climate is coming to an end. Our planet has instead entered the "Anthropocene," increasing numbers of natural scientists and cultural critics agree, a new epoch in which humanity's influence has reached geological scale. Stratigraphers may have begun to favor an official start-date of around $1950,{ }^{1}$ but many historians and social scientists have responded with their own, quite different definitions.

The most influential of these critiques argues that the responsibility for our present environmental predicament lies in the commodification of nature at the hands of a narrow capitalist elite, and accordingly relabels the new epoch the "Capitalocene." The exemplars are Britain during the First Industrial Revolution, where "fossil capitalism" was invented and exported, and the New World settler colonialism that fueled its emergence. Both of these accounts extrapolate global narratives from a narrow range of regional and temporal examples, centered on the socioeconomic dynamics of Atlantic colonialism or British industrialization. The rest of the world often appears in these accounts as a passive receptacle in which universal logics play out their inevitable historical course.

As scholars in these pages have recognized, recentering our field of vision on Asia complicates such grand narratives (Journal of Asian Studies vol. 73, no. 4 [2014]; Thomas et al. 2016). Drawing on Asian energy histories, the present analysis offers a rather different account of the Anthropocene's underlying socioeconomic dynamics. Against the existing historiographical focus on early steam power, it deploys the alternative lens of electrification. Grid electricity is the key macro-technology of the twentieth century and a crucial component of the fossil

\footnotetext{
${ }^{1}$ In August 2016 the Anthropocene Working Group presented its initial recommendation on the potential new time interval to the International Geological Congress, although the final decision on formalization is yet to be taken. The official proposal prioritizes stratigraphical clarity over deeper processes, and this article therefore concentrates instead on the burgeoning historiography of the Anthropocene.
} 
economy's spread, both horizontally across the Earth and vertically into virtually every element of contemporary life, from farms and factories to political communication. Today power and heat generation is the single largest source of anthropogenic carbon emissions worldwide, placing electricity at the heart of the climate crisis that initiated interest in the Anthropocene. It has so far received little attention from Anthropocene scholars, however, perhaps because of its technical complexity. As this account shows, the lens of electrification challenges the Capitalocene thesis of a simple relationship between colonialism and the spread of fossil capitalism. Instead, it pushes us to reevaluate the timing, key actors, and dynamics of the Anthropocene in Asia and beyond.

The first half of this article explores the histories of electrification in India, China, and (more briefly) Japan. Instead of a simple, linear process of diffusion, it shows that the electric avatar of Western-style fossil capitalism arrived in the colonial periphery belatedly, haphazardly, and reluctantly. When it did, electrification was translated into new contexts with the collaboration of indigenous players. Asian histories thus provide a much more ambivalent account of colonialism and its relationship to capitalism and climate change than admitted by Anglozone scholars. They reinforce the emerging scientific consensus that the new "age of mankind" ought to be dated to the postwar boom in energy consumption and environmental impact — the so-called "Great Acceleration" (McNeill and Engelke 2014; Steffen et al. 2015)—a dating that not coincidentally aligns with decolonization.

The article then turns to examine Asian energy sectors and the Great Acceleration. Rather than an imitation of Anglozone fossil capitalism and its logic of commodification, the expansion of electricity across Asia is more accurately characterized as a broadly shared moral project of fossil developmentalism. It was not private capitalists but the state that led electrification, 
especially favoring monumental mega-projects - an emphasis that persists despite more recent global turns towards electricity liberalization and renewable energy. Most significantly, the fossil developmentalist project did not simply deepen the entanglement of energy with the market economy. Electrification was at least partly decommodified, instead reconceptualized as a national good and increasingly as an (imperfectly recognized) entitlement to be demanded from the state. The electric economy expanded to integrate vast sections of the world's population through state-subsidized access, often to the disadvantage of industrial capitalists. This incomplete democratization of consumption extended even beyond formal democracies, as increasingly large segments of Asia's population began to regard cheap energy as a right and a necessity. Our conceptions of the current age, and our political prescriptions, must wrestle with the reality of mass - albeit hardly universal—energy consumption. The socioeconomic dynamics underlying Asian electrifications challenge us to rethink dominant accounts of the Anthropocene, and the political predicament it poses.

\section{Provincializing the Anthropocene}

Whether we focus on the deep history of Homo sapiens as the unique "fire-ape" or twentiethcentury nuclear detonations, "from almost any viewpoint energy seems to be at the heart" of the Anthropocene (McNeill and Engelke 2014, 40). One linkage between the two has received especially wide endorsement: that the new human-dominated epoch is bound up with the revolutionary shift towards large-scale combustion of fossil fuels. Fossil fuels enabled societies to burst through the Malthusian constraints faced by the old "organic economy" and its energy regime of plant, human, and animal power (Wrigley 2010; McNeill and Engelke 2014). In atmospheric chemist Paul Crutzen's original coinage, the Anthropocene's onset was accordingly 
dated via James Watt's steam engine patent in 1784 (Crutzen 2002, 23). Industrialization, rapid economic and population growth, urbanization, and consumerism automatically followed around the world. Before the provisional endorsement of a postwar start-date, this focus on the period around 1800 formed the "dominant scholarly consensus" (Mikhail 2016, 222).

In response to the growing prominence of the Anthropocene, critics have argued that the species-level human agent at the concept's heart, the Anthropos, obscures huge hierarchies of class and region. They note that an elite minority has produced and benefited from much of the world's emissions (Malm and Hornborg 2014). This "Capitalocene" critique is the most influential and sustained analysis of the Anthropocene to have emerged from the humanities and social sciences so far. Popularized by Naomi Klein (2014), even climate scientists have acknowledged its force (Steffen et al. 2015, 91).

One line of this argument, now perhaps better known as the "Plantationocene" thesis, traces fossil capitalism's origins back to the colonization of the Americas. The slavery-based extractivism that followed rationalized and appropriated human labor and the natural world for capitalist accumulation (Haraway et al. 2016; Moore 2016, 2017; Patel and Moore 2017; see also Lewis and Maslin 2015; Yusoff 2019). Such accounts have surprisingly little to say about Asian societies and their rather different experiences of colonialism, however. A second school preserves Crutzen's original chronology. As revisionist economic historians have argued, if the "ghost acres" of the colonies helped to spark industrialization, vast supplies of fossil energy were essential to sustain it and steampower's development was itself spurred by coal extraction (Wrigley 2010). In contrast, China did not possess the same conveniently located coal reserves, India did not face the same ecological pressure to innovate, and Japan opted for energy efficiencies (such as improved forest management) over fossil solutions; they thus failed to 
escape the material constraints that had limited previous economic growth (Pomeranz 2000; Parthasarathi 2011). For these revisionists, "the Industrial Revolution was above all an 'energy revolution"' (Jonsson 2012, 694). Exponents of the Capitalocene thesis have duly rebranded this confluence of technological and socioeconomic transformation the advent of "fossil capitalism" (Malm 2016; Angus 2016; Bonneuil and Fressoz 2016, 222-52). Marxisant as this literature is, it boasts both instrumentalist and structuralist strands. Some scholars highlight the role of a particular set of actors: the rising power of a private, profit-maximizing fossil capitalist class that embraced fossil energy in order to weaken the disruptive power of labor (Malm 2016; Angus 2016). More systemic approaches instead define fossil capitalism as "a way of organizing nature": the commodification and "cheapening" of natural resources, energy, and labor through the all-conquering logic of the market (Moore 2016, 17; 2017; Patel and Moore 2017).

For all its criticism of the Anthropocene's universalist pretentions, Capitalocene scholarship thus extrapolates global narratives from the histories of Atlantic colonialism and the First Industrial Revolution. "Capitalists in a small corner of the Western world" have driven a planetary-scale convergence on the fossil economy, whether through old-fashioned technological diffusion or through the coercive actions of "a clique of white British men... backed up by the power of the gun" (Malm and Hornborg 2014, 64; Bonneuil and Fressoz 2016; Malm 2016, 267; Angus 2016). ${ }^{2}$ What followed was "the 'westernization' of the world," a process of "becoming Europe"-so much so that "the Anthropocene is an Anglocene" (Altvater 2007, 37; Corlett 2013; Bonneuil and Fressoz 2016, 116). These accounts thus inadvertently replicate an old Eurocentric

\footnotetext{
${ }^{2}$ I am grateful to Julia Adeney Thomas for pointing out Bonneuil and Fressoz's reliance on classic ideas of diffusion. Malm's planned "sequel," Fossil Empire, promises to develop this link between colonial coercion and fossil technologies through an analysis centered on the steamship and the railroad.
} 
master narrative of modernity, albeit newly valorizing the supposed ecological innocence of the non-West. ${ }^{3}$

The following analysis interrogates how well these influential Capitalocene narrativesthe instrumentalist focus on "fossil capitalists" and the structuralist account of commodification - capture Asian historical experiences of fossil energy expansion. It shows that these resuscitated passive models of diffusion and domination ill fit the historical record. This is apparent even if we look at coal, but it is especially clear if we abandon the erroneous assumption that utility-scale electricity was the inevitable outgrowth of early steampower: grid electricity systems required a series of additional technical, financial, and administrative innovations, and then penetrated modern life far more comprehensively than any previous fossil technology had managed. ${ }^{4}$ Examining electrification, there is no neat relationship between European colonialism and fossil capitalism. Colonial experiences undoubtedly shaped the new significance of fossil energy in the Asian periphery, but the dissemination of fossil technologies was reluctant and haphazard, often relying on local initiative and collaboration.

If we look forward in time into the postcolonial period - to the Great Acceleration - the analytic of fossil capitalism appears to apply still less well. In much of southern and eastern Asia, the fossil economy's expansion was not driven solely by a narrow elite of capitalist manufacturers, multinational or otherwise. Instead, the state took a leading role in supporting electrification. Environmental historians have written of an early modern "developmentalist project"- "a global transformation in the management of nature and society"- that was shared across the Eurasian world-island, well beyond what would soon become the canonically

\footnotetext{
${ }^{3}$ Tellingly, for example, virtually the only Asian actors present in Bonneuil and Fressoz's survey of the Anthropocene concept are M.K. Gandhi and the "tree-huggers" of the Chipko movement (2016, 275-6, 284-5).

${ }^{4}$ This list of inventions includes everything from transformers and alternating current to lightbulb filaments. On the contingent development of such systems, see Hughes (1983).
} 
capitalist societies of western Europe (Pomeranz 2009). ${ }^{5}$ Similarly, postcolonial nationalist regimes embraced a broader project of state-directed fossil developmentalism, shared by societies that were not recognizably capitalist in the Anglozone mode. Against fossil capitalism's logic of commodification, fossil energy could not successfully be contained as an abstract market commodity: the new mass of consumers increasingly regarded it as an entitlement guaranteed by the state, albeit one imperfectly satisfied. The desire for cheap energy is no longer simply an outgrowth of capitalism's spread; it undergirds the moral economy of the modern nation-state.

\section{Capitalism, colonialism, and climate}

Many scholars of the Anthropocene posit a tight relationship between capitalism, colonialism, and climate change. As noted above, proponents of the Capitalocene thesis credit—or blamecolonialism for spreading carbon-intensive technologies such as "railways, steamships, docks, grain silos and telegraph lines" (Bonneuil and Fressoz 2016, 238; Malm 2016). Even scholars of the non-European world agree that "there is an almost unstoppable dynamic from the Industrial Revolution to the Great Acceleration since 1945" (Austin 2017, 6). Yet the histories of coal mining and electrification in Asia suggest a more complex relationship between colonialism and the fossil economy. Colonial regimes often restricted technology transfer to the periphery, even as a host of domestic actors pushed to embrace the mineral economy.

Before the advent, improvement, and spread of the steam engine, the early fossil economy looked somewhat similar in resource-rich areas both within and outside Europe. Even in London, the heart of the fossil revolution, early coal burning was primarily for popular domestic rather than industrial use (Cavert 2016). Outside Europe, the old energy regime also

\footnotetext{
${ }^{5}$ This project included intensifying land use, expanding states, increasingly settled populations, transformed physical environments, and attempts to "tame Nature." China's "commercialism without capitalism" produced strikingly similar patterns to capitalist development in Europe (Pomeranz 2009, 4-6).
} 
included modest usage of fossil fuels for local consumption, as in the case of natural gas in midimperial China, coal in eastern India, or Burma's oil wells. Although some have used such shared patterns of usage to argue for re-envisaging the Anthropocene's regional geographies, their deployment was at a small scale not comparable to later developments. Nonetheless, this evidence does dispel any notion of a fundamentally benign precolonial relationship between nonWesterners and "Nature," an interpretation occasionally expounded both by Capitalocene historians of Europe and postcolonial environmental historians alike.

Once the British expansion of the coal economy had begun in earnest, however, the classic model of passive diffusion at first appears to work reasonably well. In India, for example, interest in coal as an energy resource with more than only local applications is attributable to colonial influence. The East India Company funded a mineralogical survey of Bengal as early as 1780, and established the Geological Survey of India in 1851, driven in part by contemporary fears about coal shortages in Britain; in the nineteenth century the geology of India thus lagged only slightly behind that of the metropole (Stafford 1989, 110-11). The editor of a recent volume on India as a "coal nation" therefore declares that "the kingdom of coal as we know it in India is primarily a gift of the Raj"- though she notes that many of its technological and administrative inefficiencies can equally be traced to the colonial period (Lahiri-Dutt 2014, 10, 15).

Yet even this apparently clear example of colonial diffusion presents complexities. The imperial regime's grasp over India's resources was far from comprehensive. Even today, only about 45 percent of potential coal-bearing areas have been surveyed, and official reserve estimates remain contentious (Lahiri-Dutt 2014, 6). Moreover, coal mining was far from the purview of Europeans alone. Early mining included many indigenous entrepreneurs, including Dwarkanath Tagore, grandfather of Bengal's legendary poet, who briefly managed to control 
virtually the entire supply of fuel in the Bengal Presidency. Steamships, too, boasted significant early indigenous ownership, while Indians came to man steam fleets across the world (Ghosh 2016, 139-40). This changed with the advent of the railways, which enabled British-controlled managing agencies and the Railway Board to funnel off increasing amounts of the financial surplus. ${ }^{6}$ The last European managing agencies remained in eastern India into the mid-1960s, though after 1914 enterprising Marwaris again ran small collieries (Goswami 1989). While ownership was mixed, not until independence in 1947 would coal's use expand rapidly for residential consumers, domestic steel production, and electricity generation.

The relationship between imperialism, geology, and coal was still more complicated in China, where formal European colonialism advanced little beyond port concessions and asymmetric trade treaties. As in India, initial interest in the country's vast mineral resources was provoked by Western geologists (Wu 2015). Yet further exploration did not simply follow the India model, whereby Europeans established key institutions and amassed data. After training in various European schools - there was no single model of European geological knowledge to be passively assimilated in any case-Chinese researchers established their own geological society, surveys, and journal, trained their own students, and became increasingly bound up with nationalist projects of resistance to the European powers (Shen 2014). As in India, politically connected Chinese entrepreneurs and European engineers together established the first mines and energy-intensive industries. From the 1900s the Qing state increasingly moved to take direct control of mining rights (Wu 2015, 96-147). Nationalists increasingly argued that fossil fuel exploitation was essential for economic development and to resist further European encroachments. This belatedly echoed developments in Japan, where state-backed coal exports

\footnotetext{
${ }^{6}$ Even the early colonial railways were often powered by vast quantities of wood rather than coal, however, with ecologically devastating consequences (Parthasarathi 2017).
} 
powered the expansion of special trading ports, and so facilitated the country's transition from the unequal treaty system to imperial power in its own right (Phipps 2015).

Such a brief survey suggests that the colonial context informed the new priority accorded to mineral exploration and natural resources in India and China. Recognizing coal's importance for industrial development was a crucial feature of the induction of their elites into the fossil moral economy. Nonetheless, where it did occur, the diffusion of key fossil technologies was more complex and involved far more local collaboration than the idea of passive osmosis or external imposition recognize. If colonial encounters set the terms of the debate, it was one in which Asian nationalists and entrepreneurs actively participated.

If we move beyond coal to look at electrification, colonial dissemination was still more ambivalent. Electricity is strikingly absent in the archival record, and accordingly in historiography. The reason was that, unlike canonical technologies such as the railways or canals (which in turn boast substantial scholarly literatures), electrification itself was largely "incidental" to imperialism into at least the early twentieth century (Kale 2014b, 455). Colonialism and the electrified incarnation of fossil capitalism hardly marched in tandem.

Colonial India illustrates this imperial indifference. The Calcutta Electric Supply Corporation (CESC) began its operations in 1899, only 17 years after London and New York, and scattered officials drew up dramatic projections of the subcontinent's energy potential. Yet outside military complexes, British residential zones, and industrial belts around the major cities, electrification remained rare. The priority was to regulate the population-lighting prisons and arms factories, for example — rather than to power economic development (Rao and Lourdusamy 2010). Generation capacity increased from $130 \mathrm{MW}$ in 1920 to $598 \mathrm{MW}$ a decade later, thanks to 
a slow emergence of hydropower in some regions. Nonetheless, senior Raj officials continued to ignore growing calls for greater investment.

Provincial elites, entrepreneurs, and investors began to fill the gap. In both colonial Madras Presidency and the princely state of Mysore under indirect rule, proactive administrations directed a steady process of electrification to undergird the regions' industrial expansion (Lourdusamy 2010; Kale 2014b). In Bombay, the entrepreneurial Tata dynasty constructed a hydroelectric plant that contributed half of all India's installed capacity as late as 1917, and private utilities became sufficiently powerful that they could resist higher electricity taxes as a "tax on progress" (Kale 2014b, 465-66). The share of foreign ownership in installed generation capacity accordingly fell from around 80 percent in 1913-14 to only 31 percent in 1928-32 (Hausman et al. 2008, 32). By independence, there were five major companies with paid-up capital of more than Rs. 10 million; British interests owned one (CESC), a mix of British and Indians controlled the second, and the Tatas the other three (Lanthier 2014, 46-7). Local collaboration and capital thus played a crucial role in the geographically uneven spread of electricity under the Raj.

Cultural diffusion and skill transfers did not seamlessly accompany the relocation of technologies, however. Skeptical of Indians' technical abilities, the colonial regime was slow to encourage engineering education even despite a scarcity of skilled European technicians (Headrick 1998). ${ }^{7}$ Senior engineers, even in Indian utilities, were often British, German, or American, and after independence India continued to rely on imported technology and foreign expertise for some years. British engineers and managing agencies stayed on in some utilities

\footnotetext{
${ }^{7}$ As ever, there were regional bright spots, such as the emergence of electrical engineering courses at the Civil Engineering College, Sibpur as early as 1895 , and of a four-year specialized degree at the nationalist Jadavpur College from 1910, both in Bengal. However, electrical research and indigenous equipment manufacture lagged even in the colonial capital (Sarkar 2015).
} 
well into the 1950s, while the Tennessee Valley Authority provided the model, planners, and personnel training for the ambitious inter-State dam project of the Damodar Valley Corporation (DVC). Nonetheless, Indians were far from naïve acolytes: the DVC's actual implementation diverged from a simple relationship of American "tutelage" and Indian "emulation," as different constituencies sought to deploy American authority and models to their own ends (Klingensmith 2007). As in the case of coal, local translation played a crucial role in mediating the sluggish arrival of electric technologies in the colony.

As a result of this imperial ambivalence, in 1947 the entire generation capacity of the Indian electricity sector stood at a mere 1,362 MW, comparable to a single medium-sized coal plant today and less than 0.4 percent of Indian installed capacity in 2018. In many areas the electricity sector remained a patchwork of heterogeneous local units, without the standardization that distinguished the successful grid systems of Europe and America. One historian concludes: "At the time of its Independence, India had an electrical industry which reached the level of European nations just before 1914;" the reason it did not opt for full nationalization was "that there was actually nothing much to nationalize" (Lanthier 2014, 46, 49). Tellingly, one of the earliest major energy policy documents of the independent republic was the Forest Policy Resolution of 1952, which aimed to increase "non-commercial" energy supplies - primarily firewood, to free up dung for agriculture. By the time of decolonization, then, India had hardly shifted out of the organic energy regime.

China fared little better. Its first power plant arrived in Shanghai courtesy of a British company, and very modest foreign direct investment similarly flowed into other port enclaves to service electric tramways and industrial investments. By 1929 the largest power company in the country was controlled by the U.S. multinational American \& Foreign Power, raising fears of an 
American takeover across Asia (Hausman et al. 2008, 189). Its expansion plans were halted by the Japanese invasion of 1937, however, and its assets were seized outright after Pearl Harbor. While nascent grids developed in the largest cities, decades of colonial incursions and a bloody civil war stalled electrification's spread. In 1949 China had only 1.85 GW installed capacity. Today that figure is one thousand times larger.

Colonial India's tiny electricity sector contrasted strikingly with that of independent Japan, an example of "peripheral convergence" between the western and eastern edges of the Eurasian world-island. The beginning of Japan's transition away from the "biological Old Regime"-including its harnessing of new energy sources and intensification of land usearguably preceded the major period of its interaction with European colonialists (Thomas 2014). Japanese uptake of Western technologies was even more striking. A highly competitive electricity industry quickly developed, powered by private capital and technical personnel educated overseas. Thanks to this dynamism, "the Age of Illumination came no later to Japan than the rest of the industrializing world" (Samuels 1988, 136): by 1933 more than 90 percent of Japanese households were electrified, significantly outstripping the 68 percent figure achieved by the United States.

Mechanization of industry was almost equally precocious. This signaled Japan's movement away from an energy-saving mode of development that took advantage of its abundant labor towards rapid heavy and chemical industrialization, without the energy windfalls from which the Anglozone had benefited. The resulting bottlenecks in energy, land, and other resources helped to drive it toward imperialism. In coal-rich Manchuria, the colonial modernizing project took the form of intensive, coal-fired industrialization, accompanied by model cities complete with gas and electricity connections, all spearheaded by the state (Young 
1998). In colonial Korea, too, the Japanese state-aided push to develop a new nitrogenous fertilizer industry led to the substantial growth of the electric power industry in the name of imperial economic development (Hausman et al. 2008, 226). This nationalist program similarly reshaped the electricity sector in Japan itself: by 1940 private cartel-style "self-control" had been replaced on national security grounds by a consolidated, state-managed electric power system, albeit with significant concessions to private interests (Samuels 1988). In the prominence accorded to energy and technology and its brief flirtation with heavy state intervention in the sector, Japan presaged the trajectories that new nationalist administrations would pursue elsewhere in southern and eastern Asian in the wake of decolonization.

These divergent histories of electrification both testify to the ability of Asian societies to assimilate Euro-American technologies under some conditions, and to the European powers' ambivalence about technological transfer to the colonies. Nationalist leaders frequently pointed out that colonialism was extractive: even if colonialists did not deliberately encourage deindustrialization, they did not simply gift capital- and energy-intensive development to the peripheries. ${ }^{8}$ As the novelist Amitav Ghosh writes, "it is demonstrably the case that the imperatives of capital and empire have often pushed in different directions, sometimes producing counter-intuitive results" $(2016,117)$.

Outside the continent's eastern periphery, most of Asia's already huge populations would have to await the end of colonialism — and often well beyond - for their own electricity connections. In 1950, Asian countries produced only 7 percent of global electricity, more than three-quarters of which was Japanese. Excluding Japan, per capita consumption was one twohundredth that of the United States (Williams and Dubash 2004, 418). The postwar Great

\footnotetext{
${ }^{8}$ For India, deindustrialization remains much debated, especially for textiles. Even if colonialism did not crush local production, technological transfer was clearly limited; see Roy (2000, 114-53).
} 
Acceleration in both energy usage and environmental damage, after all, coincided with the great decolonization of countries formerly controlled by European imperial powers.

\section{Fossil developmentalism and the Great Acceleration}

Since 1950, there has been a dramatic change in both the "magnitude and rate of the human imprint" upon the Earth system, from carbon dioxide levels to deforestation and biodiversity (Steffen et al. 2015, 81). Indeed, more than half of all carbon emissions from burning fossil fuels have been produced over the last three decades. This "Great Acceleration" marked a qualitatively different intensification of the fossil economy. Postcolonial efforts at accelerated late development were not driven by an elite of capitalist producers, nor did they neatly entail the commodification of energy. Instead, the state spearheaded electrification, now conceived of as a moral project essential for the flourishing and legitimacy of the new nation. Welfare interventions sought to democratize fossil consumption by facilitating electricity access for an increasingly wide swathe of the population. Societies with quite different socioeconomic arrangements and governing ideologies, from democratic India's mixed economy to East Asian developmental states and authoritarian petro-states, thus embraced the fossil economy in ways that looked surprisingly similar. Of course, local variants were conditioned by income level, geography, resource endowments, regional political economies, and institutions. Nonetheless,

across much of southern and eastern Asia a shared postcolonial project of fossil developmentalism became visible.

In part, such convergence was driven by the unique physical characteristics of electricity. As Timothy Mitchell (2011) and Andreas Malm (2016) have reminded us in their conflicting ways, not all fossil energy is created equal: particular fossil fuels help to shape particular 
socioeconomic arrangements. Countries across the world rapidly realized that the extension and standardization of electricity grids required central coordination and huge, long-term investments, especially as ever-larger generation units became viable, often powered by coal.

At the same time, new political considerations accelerated this convergence on centralization and state direction across the ideological spectrum. Science and technology were increasingly viewed as the key drivers of development. In Lenin's famous formula, communism meant "soviet power plus the electrification of the whole country," an association so close that incandescent bulbs became affectionately known as "Ilyich lamps." The Soviet Union's early prototype for later Five-Year Plans, the GOELRO plan, focused on a distinctively centralized mode of electrification as the pillar of economic modernization (Coopersmith 1992). France and Britain nationalized their electricity industries in 1946 and 1948. Even in the United States, powerful interests came to a monopolistic "utility consensus" in the early 1900s: private monopolies operated in non-competitive markets, supplemented by heavy state regulation (Hirsh 2000). The Great Depression prompted a new phase of intensive state intervention, aiming to alleviate market failures through federal mega-initiatives like the Tennessee Valley Authority and the Rural Electrification Administration, which more than doubled the number of electrified American farms in just its first five years. At least in the energy realm, then, the most iconic avatars of market capitalism and socialist planning in certain respects looked remarkably similar at least until the 1980s. Both the Soviet Union and the United States pursued energy-intensive heavy industrialization, while preserving a crucial guiding role for the state. The difference may simply have been in their degree of efficiency and environmental destructiveness (Allen 2003). ${ }^{9}$

\footnotetext{
${ }^{9}$ Allen attributes the Soviet Union's post-Stalin slowdown in part to the decision to prioritize increasingly costly resource extraction over energy saving. A large- $n$ study similarly found that, while poor countries experienced legacy infrastructural benefits from central planning, this came at the cost of long-term "quality handicaps" in comparison with market economies (Carlin et al. 2013).
} 
Asian societies were far from the only countries to embrace state intervention in their electricity sectors, then, but the desire for accelerated national development redoubled its importance. Through electrical grids, the fledgling nation-state could be integrated and made real, as Zionists in Palestine had recognized as early as the 1920s (Meiton 2019). At the same time, electricity was an index of civilization and state success: "the very life blood of the industrial nation," as the Indian National Congress declared (1949, 71). For many postcolonial leaders electricity was not just another economic input, but a "moral technology" that provided a spectacular illustration of state power (Coleman 2017). Even North Korea's national emblem depicts the Sup'ung hydroelectric dam constructed by the colonial Japanese regime, a testament to the broadly shared technonationalist priority accorded to electricity. ${ }^{10}$

Both competing Cold War superpowers reinforced Asia's dirigiste approaches to electrification. China and North Korea replicated the Soviet Union's highly centralized systems of power planning, finance, operation, and distribution-North Korea becoming so dependent on Soviet assistance that the dissolution of the Soviet Union plunged it into a deep energy crisiswhile Soviet and Soviet-trained engineers helped to plan electricity systems across the socialist and non-aligned world. Yet perhaps its greatest influence, extending well beyond Communist countries, was as a model of accelerated electrification. Lenin's mantra was frequently invoked in India's Constituent Assembly debates around independence (Kale 2014a). Although in 1948 the country's leadership opted for a compromise solution that fell somewhat short of total nationalization - and well short of functional centralization - the Indian system also came to revolve around vertically integrated, state-owned subnational monopolies. In the country's first three decades, almost a fifth of all plan investment went to the sector.

\footnotetext{
${ }^{10}$ Today, of course, one of the most famous images of the country shows it plunged into almost total darkness while nighttime South Korea is awash with light.
} 
The Marshall Plan-era United States, and the multilateral agencies it helped to build, were almost equally committed to the idea that the continent's growing power sectors belonged in state hands. In Thailand, for example, centralized five-year planning and the creation of stateowned electricity companies were encouraged by the World Bank and USAID as part of counterinsurgency strategy (Greacen and Greacen 2004). Electric power lending was the World Bank's largest single activity for decades, and into the 1980s India, Indonesia, and Thailand were among its largest recipients. With the exception of the American client states of Japan and the Philippines, ${ }^{11}$ other Asian countries similarly nationalized their electricity industries to create vertically integrated public monopolies: Indonesia in 1950, South Korea in 1961, Malaysia in 1963, and Thailand in 1968. Under such state leadership, Asian electricity production expanded 40-fold between 1950 and 1990 (Williams and Dubash 2004). Worldwide, then, the postwar years witnessed rapid expansion of physical electricity assets not in the hands of private "fossil capitalists"-multinational electricity corporations had all but disappeared by 1978 — but within broadly state-owned frameworks.

Once centralized electricity systems began to be installed, the logic of state-led gigantism took on its own momentum. Some scholars of Anglozone fossil capitalism have seen waterpower as a labor-friendly alternative to the early days of coal (Malm 2016). Yet in postcolonial Asia it was with hydroelectricity that the technonationalist pride and utilitarian calculations characteristic of fossil developmentalism found perhaps their purest expression. Dams were the temples of modern India, Prime Minister Jawaharlal Nehru famously declared, consoling displaced villagers that "if you are to suffer, you should suffer in the interest of this country"

\footnotetext{
${ }^{11}$ In Japan, Allied pressures for fiscal retrenchment combined with the power of private electricity firms to force privatization, blocking the creation of the large state-owned enterprises found in other Asian energy sectors. This dismantling of the wartime state-managed power system, in the face of well-organized resistance, was itself nonetheless forced through by state fiat (Samuels 1988, 166).
} 
(Klingensmith 2007). In China, the reckless pursuit of such energy utopianism through hugely wasteful and often coercive building campaigns produced a vast number of big dams - today numbering some 25,000 , more than half the global total—but at the cost of mass resettlement, environmental damage, and water problems (Pietz 2015). Nuclear energy held similarly technonationalist promise for Asian countries obsessed with fossil scarcity (Abraham 1998). In India, for decades the domestic nuclear establishment forecasted that the country's prodigious reserves of thorium would deliver a future of self-sustaining energy independence, ignoring mounting evidence to the contrary (Ramana 2012). Such post-fossil developmentalism reached its apogee in Japan and France, and might have offered a modestly lower emissions trajectory to that pioneered by the energy-hungry Anglozone. Yet hydroelectricity and nuclear did little to alter the political dynamics of fossil developmentalism — neither its emphasis on state power and vast mega-projects, not its general indifference to environmental concerns.

Elsewhere in Asia, in any case, the window for post-fossil development was narrowing as coal dependence solidified. The degree to which fossil developmentalism had been internalized was visible in India's first major energy planning document, which surveyed the sector in terms of "coal replacement units" (Government of India 1965). After the coal industry was nationalized amid the power shortages of the early 1970s, the country committed to coal as the pillar of its energy policy. In China, meanwhile, coal mining had briefly declined with the disruptions of the Great Leap Forward and the Cultural Revolution, and on the eve of the reform era scarce electricity was seen as the major bottleneck restricting economic development. For a brief moment in the early 1980s it looked as though hydroelectricity had won the day, with the merger of the water and electricity ministries (Xu 2002: 89-90). Later that decade, however, decentralization and market reforms brought a rapid acceleration of coal mining. More limited 
electricity reforms followed, ushering in a parallel expansion of thermal generation capacity that tightened the link between power and coal.

As China's cautious decentralization suggests, from the 1980s state monopolies began to be challenged in the electric power industry as in the economy at large. By 1975 the long trend of improving productivity had plateaued in the Global North, and demands for deregulation were thrown into sharp relief by the oil shocks of the 1970s and the global liquidity crisis of the early 1980s (Hirsh 2000). Pioneered in Chile and Britain, electricity liberalization-corporatization, restructuring, privatization, and independent regulation - was adopted widely across Europe, the United States, Australia, and New Zealand. By the early 1990s it was taken forth internationally under the aegis of the World Bank and Asian Development Bank, which linked the liberalization prescription to future energy loans (Henisz et al. 2005). Especially after the collapse of the Soviet Union, electricity sectors across the world began to shift, if erratically, towards a new point of convergence: an increasingly market-based approach.

Powered by an economic boom, the 1990s marked the high noon of fossil capitalism in the electricity sectors of Asia. International development banks pulled back from lending to lossmaking systems, arguing that countries should instead turn to private investors who would force efficiencies. Liberalization was cast as the silver bullet for the widely divergent challenges facing the continent's electricity systems, from keeping pace with economic growth in East Asia to South Asia's high levels of theft. By the middle of the decade, tens of billions of dollars in speculative investments were flowing to Asian electricity projects each year (Williams and Dubash 2004). They were eagerly welcomed, often with scandalously generous inducements, by governments seeking easy infusions of capital. 
This exuberance rapidly shattered with the Asian financial crisis of 1997 and the California energy crisis of 2000-01. Though international consultants continued to press for liberalization, policymaker enthusiasm began to cool. In much of Asia, full-fledged privatization proved politically impossible. For all their talk of liberalization, government agencies were reluctant to relinquish control over bureaucratic turf, natural resources, or the public utilities used to dispense populist electricity subsidies (Chen 2010). Lucrative private deals and public-private partnerships came to coexist with powerful upstream public corporations and politicized and increasingly insolvent public distribution utilities (Victor and Heller 2007). The resulting statemarket hybrid systems produced a series of financial scandals and energy crises that further tarnished the so-called "World Bank template" for power reform. Both the political feasibility of the liberalization prescription and its very content were thus increasingly questioned.

Although multinational electricity corporations - including some Asian players, such as the Hong Kong firm China Light \& Power-remain visible, there is a widespread sense among electricity practitioners that liberalization has had its day. Even its greatest advocates conceded that the sector's unique characteristics make continued state intervention essential. As the liberalization template has lost its luster, public sector behemoths have flourished. Today the world's largest utility is the State Grid Corporation of China, with operations across five continents and annual revenues of $\$ 339$ billion in 2014. Such state-owned enterprises have not survived the liberalization era unchanged. Headed by entrepreneurial officials, the best of them have embraced market discipline while leveraging their political connections to secure resources and room for maneuver (Chatterjee 2017; $\mathrm{Xu}$ 2017). The state-led character of fossil developmentalism in Asia has thus proved remarkably resilient even in the face of sustained critiques. Even after the decline of communism, industry structures outside the Anglozone have 
never converged on privatization or competitive markets, nor have private corporations displaced powerful state incumbents.

Recent moves to decarbonize electricity sectors have so far more reinforced than disrupted the political logic of fossil developmentalism. In China and India, the rapid development of renewable energy has relied heavily upon state support to facilitate learning and investment, though green industrial policy has been rather more successful in the former (Lewis 2013). Both countries continue to favor huge, on-grid mega-projects such as solar parks, at the cost of the displacement, environmental damage, and local resistance that similarly characterized the earlier generation of big dams. Its advocates claim that decentralized renewables will usher in a new era of participatory "energy democracy," emancipating marginalized communities through grassroots production. In many Asian countries, electrification has indeed brought a form of halting and incomplete democratization, as we shall see, but solely in the domain of consumption. State utilities and elites will give up control over centralized grid electricity only with the greatest reluctance.

\section{Democratizing consumption: the decommodification of electricity}

To the ire of historical materialists, Dipesh Chakrabarty has speculated that "the lurch into the Anthropocene" was not simply a tale of the spread of the capitalist mode of production. It was also "globally the story of some long-anticipated social justice" in the form of " $a$ certain democratization of consumption" (Chakrabarty 2014, 15, emphasis added). In Asia, as Chakrabarty intuited, the "long anticipation" brought by late development changed the dynamics of electrification. State-led fossil developmentalism embedded electricity in a moral economy that cut against fossil capitalism's logic of commodification. 
Increasingly, it was no longer politically tenable to direct electricity overwhelmingly towards industrial interests or the urban rich, while leaving the mass of the population in the dark. Governments instead facilitated a-partial, incomplete, but still significantdemocratization of fossil energy consumption. Again crossing the ideological spectrum, the postwar growth of energy infrastructural systems was accompanied by an increased emphasis on social objectives and distributive goals rather than pure financial costs. Electrification was expanded in geographical and socioeconomic terms beyond narrow profitability, to consumers and areas — such as isolated rural villages - unable to pay the full costs and requiring crosssubsidization. It is more than trivial that the Great Acceleration's moniker echoes Karl Polanyi's "Great Transformation," with its dialectical relationship between commodification and social protection (Steffen et al. 2015, 82; Polanyi 1944). Already by the late 1930s, the Indian National Congress's Planning Committee had declared that electricity was "something more than a commodity:" "Social ideas regarding generation and supply of electricity have undergone a complete revolution in all countries of the world. From a luxury article which it was in 1903, it has become a domestic and industrial necessity comparable with water supply, and is an essential element of modern life and civilization" (Indian National Congress 1949 [1938], 71). The second phase of the Anthropocene - the Great Acceleration - was founded on a distinctive new socioeconomic dynamic: a deepening of the fossil economy, in which electricity would become not simply a commodity or an input but an essential service, an entitlement, and a social goodin aspiration, if not always in reality. Fossil fuels thereby became implicated in wider societal interests in everything from agriculture to public lighting and education.

That this new project of fossil developmentalism was not just distinct from fossil capitalism but potentially inimical to it became clear as electricity and democratization began to 
intersect. Worldwide, electrification has proved more consistent in democracies: electricity is more likely to reach their poor, rural citizens, who cannot shoulder the full cost of supply (Min 2015). More than this, democracies tend to direct a greater share of electricity to residential rather than industrial consumers (Brown and Mobarak 2009). As this suggests, democratic politics appears to increase opportunities for other socioeconomic groups to challenge "fossil capitalist" interests, directing resources away from capital accumulation towards alternative objectives.

Nowhere is this challenge more apparent than in India, where tariff and subsidy patterns illustrate how the government's overall development priorities shifted over time. While colonial electrification favored industry, the military, and the wealthiest urban residential consumers, from the 1960s a quite different pattern emerged. In the wake of Green Revolution policies to improve agricultural productivity, increasingly large power subsidies began to flow to farmers and their electric pumpsets. Agricultural electricity consumption grew at an average compound rate of over 14 percent annually between 1960-61 and 1970-71, a surge of inputs that helped to reshape agrarian class relations and inaugurate a new era of increased party-political competition (Dasgupta 2018). In many states newly wealthy farmers mobilized to block any withdrawal of the subsidies, using their electoral clout or resorting to mass protests. Political parties began competing to offer increasingly generous subsidies, so that in many subnational states middleclass residential consumers enjoyed cheap electricity and farmers paid flat rates or virtually nothing. Power theft similarly appears to increase around elections, suggesting it is also used as an informal subsidy for electorally influential groups (Min and Golden 2014). By the 1980s, electricity flows thus became the indicator of intensifying urban-rural political struggle, playing out through the democratic system. 
Industrial and commercial tariffs rose to compensate for India's high levels of subsidies and theft, becoming some of the most expensive in the world. In states with powerful farmer lobbies, such as Punjab and Andhra Pradesh, this "zero-sum game" sometimes became explicit when governments imposed power cuts on industrial consumers rather than politically important agrarian constituencies (Kale 2014a). The proliferation of subsidies left many states' power sectors financially crippled, creating a cycle of underinvestment and unreliable supply that particularly harms large consumers sensitive to the quality of power, and discourages private firms from moving into the distribution segment. ${ }^{12}$ Sustained improvements to the pricing and quality of electricity, long demanded by business lobbies, have generally arrived where farmer lobbies and democratic accountability in the form of party-political competition have been weakest (Kale 2014a; Chatterjee 2018). In the Indian case, then, the democratization of electricity has often proved antithetical to the interests of industrial and commercial capitalists. More than this, electricity cannot be maintained as a commodity to be allocated according to market pricing. It is a public service to be demanded, even if —or perhaps especially because—it does not flow seamlessly and invisibly as in the democracies of the Global North.

The massification of fossil consumption was not confined to democracies. East Asian authoritarian developmental states similarly prioritized energy expansion. In South Korea, rural development was a pillar of Park Chung-hee's image as a "man of the soil," and under the Saemaul Undong (New Village Movement) enterprising model communities were prioritized for electrification. In only fifteen years after 1965, the proportion of rural households electrified leapt from 12 percent to 98 percent, though at a heavy financial cost to poorer households (van Gevelt 2014). China, too, has provided its population with vast quantities of cheap energy faster

\footnotetext{
${ }^{12}$ On the resilience of this vicious circle and the political-economic settlements that underpin it in different states, see Dubash, Kale, and Bharvirkar (2018).
} 
than democratic India, though satellite light evidence suggests its official electrification rate of 100 percent is significantly exaggerated (Min 2015, 85). Like South Korea, it pursued a successful program of rural electrification that combined top-down control with local decentralization. There appears to be at least superficial convergence on mass energy provision between the poles of democracy and the more developmentally minded authoritarian states, though more rapacious and sclerotic authoritarian regimes such as Myanmar and North Korea continue to lag far behind.

In practice, of course, electricity does not flow evenly across even the nominally electrified areas of Asia, but with the currents of power. Within the decentralized systems that developed in rural China, "electricity mafias" of local party leaders and politically connected electricians combined to price-gouge, a problem that continued even after the central government attempted to regulate electricity prices from 2005. Farmers resorted to theft, graffitiing utility poles, and even outright attacks on electricians, to little avail (Thaxton 2016, 207-237). In much of Asia, securing access thus requires a combination of supplication and mobilization. A canonical example from Partha Chatterjee's (2004) classic study of "political society" depicts a Kolkata squatter settlement negotiating a legal communal connection, though elsewhere in South Asia anthropologists have found that even industrialists and the urban rich organize informally to secure reliable supply (Coleman 2017; Naqvi 2018). Unsurprisingly, then, electricity subsidies systematically "leak" to rich consumers, such as farmers wealthy enough to invest in large electric tubewells and middle-class urban elites running air-conditioning units. Recent studies in India found that 87 percent of residential tariff subsidies were captured by the non-poor (Mayer et al. 2015). The surge in household electrification between 1981 and 2011, when power reached 650 million additional people, could directly explain only 3-4 percent of the huge rise in the 
country's total emissions - though up to one-quarter indirectly (Pachauri 2014). As late as 2016, 240 million Indians continued to lack electricity access altogether. The benefits of electrification remain highly asymmetric, perhaps increasingly so, even as they are more widely dispersed. For all the promise of fossil developmentalism, the democratization of energy consumption has been incomplete and deeply unequal.

The weight of mass expectation has nonetheless taken on its own momentum. The citizens of both democratic and authoritarian states have come to regard energy consumption as a right and a necessity. This is strikingly apparent in the words of an Islamabad resident, as he explained to an army brigadier overseeing anti-theft efforts that his informal settlement was forced to steal power: "It's our right. If you won't give it to us, then we'll take it like this" (quoted in Naqvi 2018, 1246). Accordingly, mass protests against tariff hikes, subsidy reforms, and prolonged power outages have dogged countries across Asia in recent years. In Pakistan, urban areas around electricity shortages in the hot summer months became common in the last years of General Pervez Musharraf's authoritarian rule and continued after the civilian return to power in 2008. The major opposition party, the Pakistan Muslim League-Nawaz, successfully capitalized upon this discontent, foregrounding the energy crisis in its 2013 election manifesto (Hossain 2018). In Bangladesh, opposition to a new coal-fired power plant in the ecologically sensitive Sundarbans coalesced around the slogan "our energy, our rights" (Bedi 2018). Even in the military-steered "hybrid regime" of neighboring Myanmar, where electrification has been long neglected, a wave of candle-lit protests swept the country in 2012 to demand 24-hour electricity supply, forcing the new government to take emergency measures to boost power supplies. "The mansion of freedom stands on an ever-expanding base of fossil-fuel use," Chakrabarty $(2009,208)$ famously declared. Worldwide, it is in democracies that electricity 
consumption has become most extensive, but the entitlement to electricity access - the expected freedom to consume - is increasingly voiced by citizens even where democratization remains tenuous.

The commodification of labor and natural resources in the New World may have been crucial in igniting modern capitalism, and a narrow clique of capitalist manufacturers in Britain may have been crucial in driving forward the first phase of the fossil revolution. Yet in much of Asia electricity has proved impossible to keep contained as a capitalist commodity to be distributed only to those who can pay its full cost, or even as a gift to be handed down by the ruling elite to a grateful population. Instead, cheap energy has been decommodified. Its expansion has in part been ensured by popular demand, motivated by the surprisingly widespread idea that consistent and affordable energy access is a universal service - an idea that seems to resonate even in many areas where electric lights still shine only unevenly or not at all. This expansive vision of electrification and its imbrication in modern life reached its logical extension in a landmark 2013 judgment from the high court in the South Indian state of Tamil Nadu. Citing its impacts on education, health, and inequality, the judges ruled that access to electricity was now a human right. ${ }^{13}$

\section{Conclusion}

Much existing historical scholarship on the Anthropocene extrapolates from New World settler colonialism and the First Industrial Revolution in Britain: structuralists argue that the hallmark of energy-intensive capitalism is a logic of commodification, while instrumentalists attribute the fossil economy's spread to a narrow elite of Anglozone industrialists and their interest in promoting steam power. If we move away from the conventional fixation on early steam,

\footnotetext{
${ }^{13}$ T.M. Prakash \& Ors. v The District Collector, Tiruvannamalai \& Anr. 20136 CTC 849 (Madras).
} 
however, electrification is the crucial macro-technology through which the fossil economy expanded and deepened. This preliminary sketch of an electricity-focused history in Asia presents a very different account of the new epoch's underlying dynamics.

Against the notion that fossil capitalism and imperialism formed a single expansionary project, Asian histories of electrification show that they did not neatly align. Outside its EuroAmerican heartlands, colonialism shaped a new awareness of the world-historical significance of fossil fuels, but the spread of fossil technologies did not automatically follow. Electrification in particular was uneven, locally mediated, and belated. For the tentacular expansion of electricity across the population and into ever more arenas of social life, most of the world had to wait for the postcolonial period.

Electricity's expansion across most of postcolonial Asia arrived as a widely shared yet regionally varied project of fossil developmentalism. Nationalist desires for rapid catch-up set the stage for a leading role for the state, upon which both market and centrally planned economies converged. Under fossil developmentalism, electricity could no longer be kept confined as an abstract, profit-making commodity that served only elite interests. Increasingly large sections of the population gained access, albeit unevenly. Much of their consumption was subsidized and highly inefficient in market terms, to the detriment of the industrial and commercial interests of the sort that had driven the original resort to steam power. Through such mass consumption, electricity came to light homes, schools, city streets; it came to power factories, farms, hospitals, fans, televisions, and mobile phones. Its vast range of uses reinforced the sense that electricity was not a commodity that could be left to the market, nor primarily an input for industrial production. Instead, citizens began to claim it as a social good, an essential service that states were expected to guarantee, even if this right was often honored in the breach. 
Fossil developmentalism, with its dual hallmarks of state intervention and decommodification, is not unique to Asia. In the twentieth and twenty-first centuries it has become at least as visible a global trend as fossil capitalism, from the rural electrification programs of the New Deal to the protests of the Gilets jaunes against a fossil fuel tax in France. Yet it is in Asian societies that postcolonial nationalism supercharged fossil developmentalism, and where the sheer scale of transformation that it brought is most acutely felt. As Amitav Ghosh notes, it is mass consumption that especially distinguishes many Asian societies' contribution to our present environmental predicament: the vast growth in carbon emissions that attended the "sudden but very small expansion of the footprint of a much larger number of people, perhaps as much as half of a greatly expanded global population, late in the twentieth century" (Ghosh 2016, 123). In 1971, Asia Pacific accounted for less than one-sixth of global energy consumption; today, though per capita emissions in many countries remain low, that figure is more than half.

The new moral economy of fossil developmentalism has altered the dilemma posed by the Anthropocene. Some argue that ending capitalism would halt climate change in its tracks (Moore 2015). To be sure, elites continue to corner a disproportionate share of the fossil economy's benefits; all humanity is far from equally complicit in today's multidimensional environmental crisis, just as all humanity is far from equally vulnerable. Yet the inclusive promise of fossil consumption goes much deeper, penetrating virtually every aspect of contemporary life and its politics. The enduring desire for cheap energy will continue to shape our world.

\section{Acknowledgments}


I am grateful to everyone who read earlier drafts or commented on presentations of this work, including Gareth Austin, Dipesh Chakrabarty, Robin Fleming, Fredrik Albritton Jonsson, Prasannan Parthasarathi, Julia Adeney Thomas, Tyler Williams, Faridah Zaman, and two anonymous reviewers.

\section{List of References}

Abraham, Itty. 1998. The Making of the Indian Atomic Bomb: Science, Secrecy and the Postcolonial State. New York: Zed Books.

Allen, Robert C. 2003. Farm to Factory: A Reinterpretation of the Soviet Industrial Revolution. Princeton; Princeton University Press.

Altvater, Elmar. 2007. "The Social and Natural Environment of Fossil Capitalism.” In Colin Leys and Leo Panitch, eds, Coming to Terms with Nature. London; New York; Halifax: Merlin Press.

Angus, Ian. 2016. Facing the Anthropocene: Fossil Capitalism and the Crisis of the Earth System. New York: Monthly Review Press.

Austin, Gareth. 2017. "Introduction." In Gareth Austin, ed., Economic Development and Environmental History in the Anthropocene: Perspectives on Asia and Africa, 1-22. London: Bloomsbury Academic.

Bedi, Heather Plumridge. 2018. “'Our Energy, Our Rights': National Extraction Legacies and Contested Energy Justice Futures in Bangladesh." Energy Research \& Social Science 41: $168-175$.

Bonneuil, Christophe, and Jean-Baptiste Fressoz. 2016. The Shock of the Anthropocene. London; New York: Verso. 
Bremmer, Ian. 2010. The End of the Free Market: Who Wins the War Between States and Corporations? New York: Portfolio.

Brown, David S., and Ahmed Mushfiq Mobarak. 2009. "The Transforming Power of Democracy: Regime Type and the Distribution of Electricity." American Political Science Review 103(2): 193-213.

Carlin, Wendy, Mark Schaffer, and Paul Seabright. 2013. "Soviet Power Plus Electrification: What Is the Long-Run Legacy of Communism?" Explorations in Economic History 50(1): $116-147$.

Cavert, William M. 2016. The Smoke of London: Energy and Environment in the Early Modern City Cambridge: Cambridge University Press.

Chakrabarty, Dipesh. 2009. "The Climate of History: Four Theses.” Critical Inquiry 35(2): 197222.

Chakrabarty, Dipesh. 2014. "Climate and Capital: On Conjoined Histories." Critical Inquiry 41(1): 1-23.

Chatterjee, Elizabeth. 2017. "Reinventing State Capitalism in India: A View from the Energy Sector." Contemporary South Asia 25(1): 85-100.

Chatterjee, Elizabeth. 2018. "The Politics of Electricity Reform: Evidence from West Bengal, India." World Development 104: 128-39.

Chatterjee, Partha. 2004. The Politics of the Governed: Reflections on Popular Politics in Most of the World. New York: Columbia University Press.

Chen, Ling. 2010. "Playing the Market Reform Card: The Changing Patterns of Political Struggle in China's Electric Power Sector." The China Journal 64: 69-95. 
Coleman, Leo. 2017. A Moral Technology: Electrification as Political Ritual in New Delhi. Ithaca: Cornell University Press.

Coopersmith, Jonathan. 1992. The Electrification of Russia, 1880-1926. Ithaca; London: Cornell University Press.

Corlett, Richard T. 2013. "Becoming Europe: Southeast Asia in the Anthropocene," Elementa: Science of the Anthropocene 1 [online].

Crutzen, Paul J. 2002. “Geology of Mankind.” Nature 415(6867): 23.

Dasgupta, Aditya. 2018. "Technological Change and Political Turnover: The Democratizing Effects of the Green Revolution in India." American Political Science Review 112(4): 918938.

Dubash, Navroz, Sunila S. Kale, and Ranjit Bharvirkar, eds. 2018. Mapping Power: The Political Economy of Electricity in India's States. New Delhi: Oxford University Press.

Elverskog, Johan. 2014. “(Asian Studies + Anthropocene) $)^{4}$.” Journal of Asian Studies 73(4): 963-974.

Ghosh, Amitav. 2016. The Great Derangement: Climate Change and the Unthinkable. Gurgaon, India: Allen Lane.

Goswami, Omkar. 1989. "Sahibs, Babus, and Banias: Changes in Industrial Control in Eastern India, 1918-50." Journal of Asian Studies 48(2): 289-309.

Government of India. 1965. Report of the Energy Survey of India Committee. New Delhi: Government of India.

Greacen, Chuenchom Sangarasri, and Chris Greacen. 2004. “Thailand's Electricity Reforms: Privatization of Benefits and Socialization of Costs and Risks." Pacific Affairs 77(3): 517541. 
Haraway, Donna, Noboru Ishikawa, Scott F. Gilbert, Kenneth Olwig, Anna L. Tsing, and Nils Bubandt. 2016. "Anthropologists Are Talking-About the Anthropocene." Ethnos 81(3): $535-564$.

Hausman, William J., Peter Hertner, and Mira Wilkins. 2008. Global Electrification: Multinational Enterprise and International Finance in the History of Light and Power, 1878-2007. Cambridge; New York: Cambridge University Press.

Headrick, Daniel R. 1988 The Tentacles of Progress: Technology Transfer in the Age of Imperialism, 1850-1940. New York; Oxford: Oxford University Press.

Henisz, Witold J., Bennet A. Zelner, and Mauro F. Guillén. 2005. “The Worldwide Diffusion of Market-Oriented Infrastructure Reform, 1977-1999.” American Sociological Review 70(6): $871-897$.

Hirsh, Richard F. 2000. Power Loss: The Origins of Deregulation and Restructuring in the American Electric Utility System. Cambridge, MA: MIT Press.

Hossain, Naomi. 2018. "Energy Protests in Fragile Settings: The Unruly Politics of Provisions in Egypt, Myanmar, Mozambique, Nigeria, Pakistan, and Zimbabwe, 2007-2017.” IDS Working Paper 2018-513. Brighton: Institute of Development Studies.

Hughes, Thomas P. 1983. Networks of Power: Electrification in Western Society, 1880-1930. Baltimore; London: Johns Hopkins University Press.

Indian National Congress. 1949. Power and Fuel: Report of the Sub-Committee. National Planning Committee Series, ed. K.T. Shah. Power and Fuel. Bombay: Vora.

Jonsson, Fredrik Albritton. 2012. "The Industrial Revolution in the Anthropocene." Journal of Modern History 84(3): 679-96. 
Kale, Sunila S. 2014a. Electrifying India: Regional Political Economies of Development. Stanford, CA: Stanford University Press.

Kale, Sunila S. 2014b. "Structures of Power: Electrification in Colonial India." Comparative Studies of South Asia, Africa and the Middle East 34(3): 454-475.

Klein, Naomi. 2014. This Changes Everything: Capitalism vs. the Climate. Toronto: Knopf.

Klingensmith, Daniel. 2007. "One Valley and a Thousand": Dams, Nationalism, and Development. New Delhi: Oxford University Press.

Lahiri-Dutt, Kuntala. ed. 2014. The Coal Nation: Histories, Ecologies and Politics of Coal in India Farnham; Burlington, VT: Ashgate.

Lanthier, Pierre. 2014. "From the Raj to Independence: British Investment in the Indian Electricity Sector," Utilities Policy 29: 44-53.

Lewis, Joanna I. 2013. Green Innovation in China: China's Wind Power Industry and the Global Transition to a Low-Carbon Economy. New York: Columbia University Press.

Lewis, Simon L., and Mark A. Maslin. 2015. "Defining the Anthropocene." Nature 519(7542): $171-180$.

Malm, Andreas. 2016. Fossil Capital: The Rise of Steam Power and the Roots of Global Warming. London; New York: Verso.

Malm, Andreas, and Alf Hornborg. 2014. "The Geology of Mankind? A Critique of the Anthropocene Narrative." Anthropocene Review 1(1): 62-69.

Mayer, Kristy, Sudeshna Ghosh Banerjee, and Chris Trimble. 2015. Elite Capture: Residential Tariff Subsidies in India. World Bank Studies. Washington, DC: World Bank. 
McNeill, John R., and Peter Engelke. 2014. The Great Acceleration: An Environmental History of the Anthropocene since 1945. Cambridge, MA: Belknap Press of Harvard University Press.

Meiton, Fredrik. 2019. Electrical Palestine: Capital and Technology from Empire to Nation. Oakland, CA: University of California Press.

Mikhail, Alan. 2016. "Enlightenment Anthropocene.” Eighteenth-Century Studies 49(2): 211231.

Min, Brian. 2015. Power and the Vote: Elections and Electricity in the Developing World. New York: Cambridge University Press.

Min, Brian, and Miriam Golden. 2014. "Electoral Cycles in Electricity Losses in India." Energy Policy 65: 619-25.

Mitchell, Timothy. 2011. Carbon Democracy: Political Power in the Age of Oil. London: Verso.

Moore, Jason W. 2015. Capitalism in the Web of Life: Ecology and the Accumulation of Capital. London; New York: Verso.

Moore, Jason W. ed. 2016. Anthropocene or Capitalocene? Nature, History, and the Crisis of Capitalism. Oakland, CA: PM Press.

Moore, Jason W. 2017. "The Capitalocene, Part I: On the Nature and Origins of Our Ecological Crisis." Journal of Peasant Studies 44(3): 594-630.

Naqvi, Ijlal. 2018. “Contesting Access to Power in Urban Pakistan.” Urban Studies 55(6): 1242 1256.

Pachauri, Shonali. 2014. "Household Electricity Access a Trivial Contributor to $\mathrm{CO}_{2}$ Emissions Growth in India." Nature Climate Change 4(12): 1073-1076. 
Patel, Raj, and Jason W. Moore. A History of the World in Seven Cheap Things: A Guide to Capitalism, Nature, and the Future of the Planet. London: Verso.

Phipps, Catherine L. 2015. Empires on the Waterfront: Japan's Ports and Power, 1858-1899. Cambridge, MA: Harvard University Press.

Pomeranz, Kenneth. 2000. The Great Divergence: Europe, China, and the Making of the Modern World Economy. Princeton: Princeton University Press.

Pomeranz, Kenneth. 2009. "Introduction: World History and Environmental History." In Edmund Burke, III and Kenneth Pomeranz, eds., The Environment and World History, 3-32. Berkeley, CA: University of California Press.

Parthasarathi, Prasannan. 2011. Why Europe Grew Rich and Asia Did Not: Global Economic Divergence, 1600-1850. Cambridge: Cambridge University Press.

Parthasarathi, Prasannan. 2017. "Forests and a New Energy Economy in Nineteenth-Century South India." In Gareth Austin (ed.), Economic Development and Environmental History in the Anthropocene: Perspectives on Asia and Africa, 145-158. London: Bloomsburg Academic.

Pietz, David A. 2015. The Yellow River: The Problem of Water in Modern China. Cambridge, MA: Harvard University Press.

Polanyi, Karl. 1944. The Great Transformation. New York: Farrar \& Rinehart.

Ramana, M.V. 2012. The Power of Promise: Examining Nuclear Energy in India. New Delhi: Penguin Viking.

Rao, Srinivasa, and John Lourdusamy. 2010. "Colonialism and the Development of Electricity: The Case of Madras Presidency, 1900-47.” Science, Technology \& Society 15(1): 27-64. 
Roy, Tirthankar. 2000. The Economic History of India, 1857-1947. New Delhi; Oxford: Oxford University Press.

Samuels, Richard J. 1988. The Business of the Japanese State: Energy Markets in Comparative and Historical Perspective. Ithaca, NY: Cornell University Press.

Sarkar, Suvobrata. 2015. "Domesticating Electric Power: Growth of Industry, Utilities and Research in Colonial Calcutta." Indian Economic and Social History Review 52(3): 35789.

Shen, Grace Yen. 2014. Unearthing the Nation: Modern Geology and Nationalism in Republican China. Chicago: University of Chicago Press.

Stafford, Robert A. 1989. Scientist of Empire: Sir Roderick Murchison, Scientific Exploration and Victorian Imperialism. Cambridge; New York: Cambridge University Press.

Steffen, Will et al. 2015. "The Trajectory of the Anthropocene: The Great Acceleration." Anthropocene Review 2(1): 81-98.

Thaxton, Ralph. 2016. Force and Contention in Contemporary China: Memory and Resistance in the Long Shadow of the Catastrophic Past. New York: Cambridge University Press.

Thomas, Julia Adeney. 2014. "Reclaiming Ground: Japan's Great Convergence." Japanese Studies 34(3): 253-63.

Thomas, Julia Adeney, Prasannan Parthasarathi, Rob Linrothe, Fa-Ti Fan, Kenneth Pomeranz, and Amitav Ghosh. 2016. “JAS Round Table on Amitav Ghosh, The Great Derangement: Climate Change and the Unthinkable." Journal of Asian Studies 75(4): 929-955.

van Gevelt, Terry. 2014. "Rural Electrification and Development in South Korea." Energy for Sustainable Development 23: 179-187. 
Victor, David G., and Thomas C. Heller. eds. 2007. The Political Economy of Power Sector Reform: the Experiences of Five Major Developing Countries. Cambridge: Cambridge University Press.

Williams, James H., and Navroz K. Dubash. 2004. "Asian Electricity Reform in Historical Perspective," Pacific Affairs 77(3): 411-436.

Wrigley, E.A. 2010. Energy and the English Industrial Revolution. Cambridge: Cambridge University Press.

Wu, Shellen Xiao. 2015. Empires of Coal: Fueling China's Entry into the Modern World Order, 1860-1920. Stanford, CA: Stanford University Press.

$\mathrm{Xu}$ Yi-chong. 2002. Powering China: Reforming the Electric Power Industry in China. Aldershot: Ashgate Dartmouth.

Xu Yi-chong. 2017. Sinews of Power: The Politics of the State Grid Corporation of China. New York: Oxford University Press.

Young, Louise. 1998. Japan's Total Empire: Manchuria and the Culture of Wartime Imperialism. Berkeley: University of California Press.

Yusoff, Kathryn. 2018. A Billion Black Anthropocenes or None. Minneapolis: University of Minnesota Press. 